\title{
Crisis in Our University Libraries
}

BY ROBERT B. DOWNS

$T$

HE GREAT UNANSWERED QUESTION in the minds of American librarians, as they attempt to peer a mere decade into the future, is whether they can run fast enough to stand still. There is considerable evidence that they are beginning to slip back two paces for every step forward. One need not be a Cassandra to view the period ahead with trepidation.

One basic factor in the situation-affecting, of course, the whole world of higher education-is the mounting tide of student enrollment threatening to inundate the colleges and universities of the country. The growth in recent years has been almost geometrical. In 1946-47, reflecting the large influx of returning war veterans, the number of college students in the United States for the first time exceeded 2,000,000. The tide receded somewhat five years later, as the wartime generation moved out, but in 1952 the growth curve started a sharp and uninterrupted ascent, with every indication that it will end in the stratosphere. In 1957, enrollment went past the 3,000,000 mark, and in the current year, 196061 , only three years later, the figure is approximately 4,000,000. A conservative estimate by the American Council on Education projects a total of $5,000,000$ for 1965 , and an enrollment of $6,500,000$ by 1970.1

Meanwhile, confronted by expanding demands on every front, university libraries have been caught in an upward spiral of inflation. They have seen salaries, wages, books, periodical subscriptions, binding, equipment, and supplies in a virtually unbroken rise. Faculties

1 American Universities and Colleges, 8th ed., (Washington, D. C., American Council on Education, 1960), p. 27.
Dr. Downs is Dean of Library Administration, University of Illinois.

and staffs have doubled, or even trebled, in many institutions. New departments have been created, requiring additional library facilities. The rate of publishing and the variety of materials published are being stepped up dramatically.

As they struggle to cope with the insistent pressures upon them, are the libraries receiving appropriate financial support? In individual instances, yes, though from an overall standpoint, the answer, unfortunately, is in the negative.

A standard measuring stick is the relationship between expenditures for library resources and services and for total educational purposes. For 1945-46, the annual compilation of "College and University Library Statistics", sponsored by ACRL, included thirty institutions in Group I, "University-Type" libraries. Fifteen years ago, these institutions were devoting a median of 4.86 per cent of their total educational expenditures to the maintenance and development of their libraries. By 1958-59, however, the median figure for libraries in the same group had declined to 3.7 per cent. ${ }^{2}$ In only a handful of institutions was there a contrary trend-principally universities where a combination of a libraryminded president and dynamic library leadership were affecting a rejuvenation of a moribund library system.

A further analysis was assayed recently by Frank Lundy, director of Libraries at the University of Nebraska, on the basis

\footnotetext{
3 CRI, VIII (1947), 261; XXI (1959). 31.
} 
of the ACRL statistics. ${ }^{3}$ Summarizing data provided by 106 universities, arranged in order of library support, Lundy reported a range from a generous 7.8 per cent at Rice Institute to a miserly 1.2 per cent at New York University. Percentagewise, state institutions seemed to fare rather less well than the privately supported universities; actually, both types were well represented among the highs and the lows. As a point of reference it should be noted that university library surveyors have almost invariably recommended 4 per cent as the minimum level of support for the provision of reasonably adequate library service.

One of the most conspicuous areas in which much is expected of libraries, without corresponding reciprocity on the part of the receivers, is in the broad field of research, especially contract research in science and technology. Expenditures for organized research in American universities increased by nearly 900 per cent in the decade from 1940 to 1950 and has continued to rise year by year. Consider the following figures supplied by the $\mathrm{Na}$ tional Science Foundation:

$\begin{array}{lr}1953-54 & \$ 450,000,000 \\ 1954-55 & 480,000,000 \\ 1955-56 & 530,000,000 \\ 1956-57 & 600,000,000 \\ 1957-58 & 720,000,000 \\ 1958-59 & 840,000,000 \\ 1959-60 & 1,000,000,000\end{array}$

The percentage increase, 1953-1960, was 126.4

From the same source, in a tabulation of "Expenditures for Separately Budgeted Research and Development in Colleges and Universities by Field of Science, Character of Work, and Source of Support, Fiscal Year 1958", total expenditures of $\$ 735,800,000$ were reported, divided among four major fields:

3 University Library Statistics of Interest to You, (Lincoln: University of Nebraska Libraries, April 5 , 1960), Processed., 4 pp.

'U. S. National Science Foundation, Reviews of Data on Research and Development, No. 16 (December 1959). 3 .

\author{
Engineering \\ Physical Sciences \\ Life Sciences \\ Social Sciences
}

$\$ 186,400,000$

$262,300,000$

$251,500,000$

$35,600,000$

Of the total, $\$ 537,800,000$ was derived from federal funds, and $\$ 198,100,000$ from non-federal sources (institutions' own funds, foundations, health agencies, industry, gifts and grants)-proof of the dominant role of the federal government in financing present-day research. ${ }^{5} \mathrm{~A}$ similar report noted total expenditures of $\$ 105,500,000$ for scientific research, 1957 58 , in the nation's medical schools. ${ }^{6}$

By nature, research is constantly changing, dividing, and extending. As a corollary, the library on which research primarily depends must be highly adaptable, modifying its program to meet changing requirements. New departments are created and research interests in established departments undergo radical revisions-all causing an immediate impact on the library, its resources, and its services. The library can hardly fulfill its proper role as a dynamic, living organism capable of growing to meet multiple demands, without the life blood of strong financial backing.

While federal agencies, foundations, industries, and other organizations are pouring funds into colleges and universities for pure and applied research-almost beyond the capacity, in some cases, of the institutions to absorb them-the libraries on which such research has to be based are too frequently accorded niggardly treatment. In essence, the libraries are being called upon to do more and more on less and less, proportionately speaking. Seldom is any specific provision made, in the many rich research grants, for library materials and services, lacking which the planned investigations would be seriously handicapped if not brought to a complete standstill.

Among the troublesome aspects of uni-

"Idem, No. 19 (April 1960), 6.

o Idem, No. 17 (January 1960), 3

COLLEGE AND RESEARCH LIBRARIES 
versity and research library financing is the inflation in costs of materials. Using 1947-49 prices for an index dollar, and based on 2,347 titles in a total of twentyfour subject areas, a recent survey shows that the average subscription price for serial publications has increased from $\$ 3.55$ in $1946-47$ to $\$ 5.27$ in 1960 , or 48.5 per cent. Broken down by fields, the average subscription prices had jumped from 31.5 to 70.7 per cent, with the largest increases occurring in mathematics, chemistry, physics, botany, geology, and other branches of science. ${ }^{7}$ Noteworthy examples are Chemical Abstracts, which in the past five years has increased from $\$ 60$ to $\$ 200$ per year; Chemisches Zentralblatt from $\$ 90$ to $\$ 240$; Biochimica et Biophysica Acta from $\$ 36$ to $\$ 144$; and Biological Abstracts from $\$ 50$ to $\$ 136$.

More alarming and breeding more insoluble dilemmas for libraries is the phenomenal growth of the book world. Books, magazines, newspapers, and other types of printed matter are produced by the presses at a rate that would have appeared miraculous even a generation ago. The average annual world book production has risen from about 156,000 titles in 1940 to 240,000 today and has reached an astronomical total of five billion copies. ${ }^{8}$ Quantities are equally staggering in the fields of serial and government publications. Science, the most prolific field in serials, is authoritatively estimated to account for 50,000 current periodicals. In biology alone, 21,000 journals are presently being issued. The standard guide to the literature of chemistry, Chemical Abstracts, regularly analyzes the contents of more than 7,000 journals from some ninety different countries. The figures for mathematics, physics, and other sciences are comparable.

7 Helen M. Welch, "Cost Indexes for U. S. Periodicals," Library Resources and Technical Services, IV (1960), 150-57. See also: William H. Huff, and Norman B. Brown. "Serial Services Cost Indexes." Idem, IV (1960). 158-60, and William H. Kurth. "U. S. Book and Periodical Price," Library Journal, LXXXV (196n). 54-57.

( "World Production; 5,000 Million Books a Year," UNESCO Courier, (February 1957), pp. 20-21.
The area of government publishing is another striking illustration of the accelerated production of printed matter. From international, national, provincial, state, and local governments throughout the world comes a tidal wave of books, pamphlets, journals, and reports.

Still another highly significant factor in the situation is the ever-widening scope of library collecting activities. With few exceptions, American libraries have traditionally limited their procurement efforts to materials in western European languages. But with the increasingly important role played by the United States in world politics, the recognition of certain critical areas of the world, and the numerous area-study programs being developed in colleges and universities, the nation's research libraries are undertaking aggressive and ambitious acquisition plans in languages and regions previously unknown to or neglected by them. For example, the Association of Research Libraries' Farmington Plan Committee charged with obtaining on a cooperative basis at least one copy of every significant book published abroad-has established seven area sub-committees to insure thorough coverage of all countries. These efforts could be strengthened substantially by implementation of Public Law 480 , to set up machinery and to provide funds for the procurement of library materials from certain difficult parts of the world.

In reviewing the resources of libraries and their ability to support advanced study and research, attention should be directed also at the existing inequitable distribution of facilities among the major regions of the country. The scholar and the research worker in certain areas are badly handicapped by the absence of adequate materials close at hand and must depend upon richer libraries elsewhere. of 109 centers containing more than 500,000 volumes within a fifty-mile radius, seventy are in the northeastern quarter of the United States. There are 
held in these 109 centers $290,000,000$ volumes, of which only $65,000,000$ are outside the Northeast. ${ }^{9}$

Closely allied to the problem of maldistribution is the inadequacy of numerous university libraries attempting to support doctoral programs. A cursory examination of expenditures for books and volume holdings of the more than a hundred American universities now granting the doctorate in various fields offers convincing evidence that some institutions simply lack sufficient library resources to support anything beyond undergraduate, or at most master's level, work.

An obvious conclusion to be drawn from the conditions described in the foregoing discussion is that university libraries must find additional sources of financial assistance if quality and strength are to be maintained in higher education and educational standards not permitted to sink into mediocrity. Increased appropriations from their parent institutions, federal aid, foundation grants, and a proper share of research contract funds seem the most logical and promising ๑ Robert B. Downs. "Distribution of American Li-
brary Resources," CRL, XVIII (1957), 183-89, 235-37. sources from which to meet a rapidly developing crisis.

There will doubtless be a temptation, as huge student enrollments begin to swamp university campuses, to cheapen the quality of educational programs. Confronted by multitudes of students, some colleges and universities will resort to mass methods of instruction. Their faculties may return to the old singletextbook plan for undergraduates. Institutions concerned with producing welleducated citizens, however, will avoid such techniques. In every way possible they will encourage independent work and study on the part of students, and for them the library will be the heart of the educational process. Certainly, at more advanced levels, scholars and graduate students in the humanities and social sciences recognize libraries as indispensable laboratories. Books and journals are equally essential to the pure and applied sciences, for the scientist, like the humanist and social scientist, requires records of previous investigations and experiments to save him from duplication of effort and to provide a foundation for further progress.

\section{Quality Comes From Service Rather Than From Size}

Size [of a library's collection] is less important than service. The way the collection is housed and used, through the administrative competence of a professional staff, makes the difference in quality. In turn, the strength of the library is beyond question a reliable gauge for measuring the excellence of the total program of higher education in a given institution-Wake Up and Read, a Few Facts About College and University Libraries (New York, Council on Financial Aid to Education, Inc. [1960]). 